\title{
Perencanaan Arsitektur Enterprise Perseroan Terbatas Arcon Reality Menggunakan Pendekatan Spewak
}

\author{
${ }^{1}$ Cecep Kurnia Sastradipraja, ${ }^{2}$ Adhitia Erfina, ${ }^{3}$ Juandi, \\ ${ }^{123}$ Sistem Informasi, Universitas Nusa Putra, Indonesia \\ ${ }^{1}$ cecep.kurnia@nusaputra.ac.id, ${ }^{2}$ adhitia.erfina@nusaputra.ac.id, ${ }^{3}$ mailto:Jhuaan197@gmail.com
}

\begin{tabular}{|c|c|}
\hline ARTICLE INFO & ABSTRACT \\
\hline Article History: & $\begin{array}{l}\text { Abstract: This research aims to produce a prototype by making an } \\
\text { enterprise architecture planning model at PT. Arcon Realitindo (Reality }\end{array}$ \\
\hline Received : 18-09-2018 & Group), where currently not all business processes in each unit are \\
\hline Revised : 11-11-2018 & supported by information systems. Based on these problems, it is \\
\hline : $23-11-2018$ & necessary to have an information system development guide that can \\
\hline Online $\quad: 30-11-2018$ & integrate all business processes in the company. The research stages \\
\hline $\begin{array}{l}\text { Keywords: } \\
\text { EAP; Spewak; Arcon } \\
\text { Realty; Real Estate }\end{array}$ & $\begin{array}{l}\text { were carried out based on the Spewak method approach, namely } \\
\text { conducting business modeling, reviewing current systems and } \\
\text { technology, creating architectural, architectural, and technology data. } \\
\text { This research produces } 12 \text { prototypes of information systems for the } \\
\text { realization of business activities at PT. Arcon Realty. }\end{array}$ \\
\hline & $\begin{array}{l}\text { Abstrak: Penelitian ini bertujuan untuk menghasilkan prototipe dengan } \\
\text { membuat model perencanaan arsitektur enterprise pada PT. Arcon }\end{array}$ \\
\hline 南田。 & $\begin{array}{l}\text { Realitindo (Reality Group), dimana saat ini tidak semua proses bisnis } \\
\text { pada setiap unit mendapatkan dukungan sistem informasi. Berdasarkan } \\
\text { permasalahan tersebut perlu adanya panduan pengembangan sistem } \\
\text { informasi yang mampu mengintegrasikan semua proses bisnis pada } \\
\text { perusahaan. Tahapan penelitian dilaksanakan berdasarkan pendekatan } \\
\text { metode spewak yaitu melakukan pemodelan bisnis, peninjauan sistem } \\
\text { dan teknologi saat ini, pembuatan arsitektur data, arsitektur aplikasi, } \\
\text { dan arsitektur teknologi. Pada penelitian ini menghasilkan } 12 \text { prototipe } \\
\text { sistem informasi untuk realisasi aktivitas bisnis pada perusahaan PT. } \\
\text { Arcon Realty. }\end{array}$ \\
\hline
\end{tabular}

\section{A. LATAR BELAKANG}

Perkembangan teknologi yang sangat pesat disertai dengan meningkatnya persaingan bisnis saat ini menuntut sebuah perusahaan agar mampu memberikan informasi yang lebih lengkap dan akurat (Ati et al., 2014), baik untuk kepentingan internal maupun eksternal perusahaan. Dengan perkembangan arus informasi yang meningkat juga kebutuhan teknologi informasi dirasakan sangat penting sebagai salah satu faktor penentu keberhasilan dalam persaingan bisnis (Indrayani, 2012), dalam hal ini peranan komputer diperlukan dalam membantu melaksanakan aktivitas setiap pegawai sesuai dengan jabatan dan tugasnya.

Dewasa ini tidak sedikit perusahaan yang bergerak dibidang perumahan belum didukung melalui pemanfaatan teknologi. Sebagai salah satu contoh adalah PT. Arcon Reality yang mempunyai misi dibidang pembangunan dan penjualan perumahan, namun dalam pelaksanaannya, pengolahan dan pemrosesan data yang dilakukan masih manual yaitu penggunaan aplikasi perkantoran Ms. Office sehingga berdampak pada efektifitas 
data dan teknologi, misalnya dalam penyimpanan data konsumen yang tidak tertata dengan baik dan tercecer karena tidak adanya sistem pengelolaan basis data. Selain itu kondisi di PT. Arcon Reality saat ini baru tersedia satu aplikasi yang berupa produk Zahir Accounting yang digunakan oleh divisi accounting. Hal ini tentu tidak akan terjadi jika PT. Arcon Realty memiliki sebuah perencanaan dalam membangun sebuah sistem informasi melalui pendekatan Enterprise architecture (EA) yang dapat menghasilkan sebuah blueprint sebagai rencana induk sistem informasi dimasa yang akan datang (Solihin, 2015).

Berdasarkan latar belakang tersebut diatas maka penelitian ini bertujuan untuk membuat perencanaan arsitektur enterprise pada PT. Arcon Reality menggunakan pendekatan metode Spewak. Dalam hal ini, Enterprise Architecture Planning (EAP) dapat digunakan dalam pembuatan blueprint teknologi informasi pada enterprise dengan menggunakan pendekatan EAP Spewak. Metodologi spewak EAP memberikan pendekatan sistematis dan metodis untuk mendefinisikan cetak biru untuk data, aplikasi, dan arsitektur teknologi yang selaras dengan visi dan strategi bisnis (Chew \& Gottschalk, 2012). Pada akhirnya, penelitian ini akan menghasilkan rencana induk sistem informasi. Perencanaan dan rancangan dalam wujud blueprint dengan rekomendasi rencana implementasi atau migrasi sistem dimasa mendatang (Kurniawan \& Chazar, 2015). Dengan adanya implementasi dari sistem ini, diharapkan dapat mempermudah karyawan dalam menangani setiap permasalahan yang ada.

\section{B. METODE PENELITIAN}

Langkah-langkah pada penelitian ini mengacu pada metodologi dari Enterprise Architecture Planning (EAP) dengan menggunakan kerangka kerja metode Spewak. Langkah-langkah penelitian dapat dilihat pada gambar 1 dari kerangka penelitian berikut:

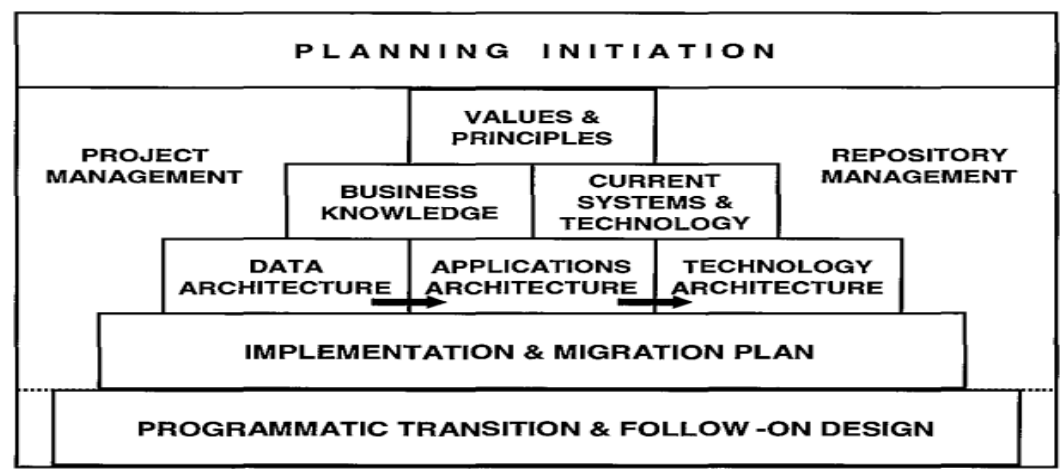

Gambar 1. The Updated EAP Model - Circa 2006 (Steven \& Michael, 2006)

Adapun untuk pengumpulan data dilakukan dengan teknik studi observasi dengan mengamati secara langsung proses bisnis yang sedang berjalan di PT. Arcon Realty, wawancara dilakukan dengan mengajuukan sejumlah pertanyaan kepada stakeholder perusahaan, penyebaran angket, dan studi literature primer, dengan cara mengumpulkan data-data yang ada pada obyek yang diteliti.

\section{HASIL DAN PEMBAHASAN}

\section{Principle Catalog}

Pada tahap ini dilakukan pengidentifikasian dan selanjutnya menetapkan prinsipprinsip sebagai acuan dalam perencanaan arsitektur enterprise (Rozak et al., 2017), khususnya pada PT. Arcon Realty. Pada tahapan ini dilakukan melalui wawancara dengan stakeholder perusahaan. Katalog prinsip arsitektur enterprise tersebut dapat dilihat pada tabel 1 berikut ini. 
Tabel 1. Principle Catalog

\begin{tabular}{|c|c|c|}
\hline No. & Prinsip & Keterangan \\
\hline 1 & $\begin{array}{l}\text { Prinsip- } \\
\text { prinsip } \\
\text { Bisnis }\end{array}$ & $\begin{array}{l}\text { a. Enterprise Architecture yang dibuat harus sesuai dengan } \\
\text { tujuan ,aktivitas tupoksi (tugas pokok dan fungsi), Dan kebutuhan } \\
\text { bisnis dari PT Arcon Reality } \\
\text { b. Prinsip prinsip yang dibuat harus berlaku pada setiap bagian PT } \\
\text { Arcon Reality } \\
\text { c. Pengelolaan enterprise architecture harus mudah dan efisiensi } \\
\text { sehingga meningkatkan kerja sama antar bagian di PT Arcon } \\
\text { Reality }\end{array}$ \\
\hline 2 & $\begin{array}{l}\text { Prinsip } \\
\text { Prinsip } \\
\text { Data }\end{array}$ & $\begin{array}{l}\text { a. Data dikelola dengan baik untuk memastikan tempat } \\
\text { penyimpanan, akurasi, dan data bisa diakses } \\
\text { b. Data didefinisikan secara konsisten dan definisi tersebut dapat } \\
\text { dimengerti dan tersedia untuk semua user } \\
\text { c. Data dilindungi dari penggunaan dan publikasi } \\
\text { yang tidak terizin. }\end{array}$ \\
\hline 3 & $\begin{array}{l}\text { Prinsip- } \\
\text { prinsip } \\
\text { Aplikasi }\end{array}$ & $\begin{array}{l}\text { a. Aplikasi dapat beroperasi pada berbagai flatform teknologi } \\
\text { sehingga aplikasi bisa dikembangkan dan dioperasikan dengan } \\
\text { lebih efektif dan efisien } \\
\text { b. Aplikasi aplikasi mudah digunakan oleh user, sehingga user dapat } \\
\text { focus pada tugasnya. }\end{array}$ \\
\hline 4 & $\begin{array}{l}\text { Prinsip- } \\
\text { prinsip } \\
\text { Teknolo } \\
\text { gi }\end{array}$ & $\begin{array}{l}\text { a. Enterprise architecture harus dirancang untuk memudahkan } \\
\text { penambahan dan pengembangan di masa depan } \\
\text { b. Menggunakan sofware,hardware,dan platform yang telah } \\
\text { distandarkan untuk mencegah data yang tidak kompatibel dengan } \\
\text { teknologi yang digunakan }\end{array}$ \\
\hline
\end{tabular}

1. Business Modelling

a. Struktur Organisasi

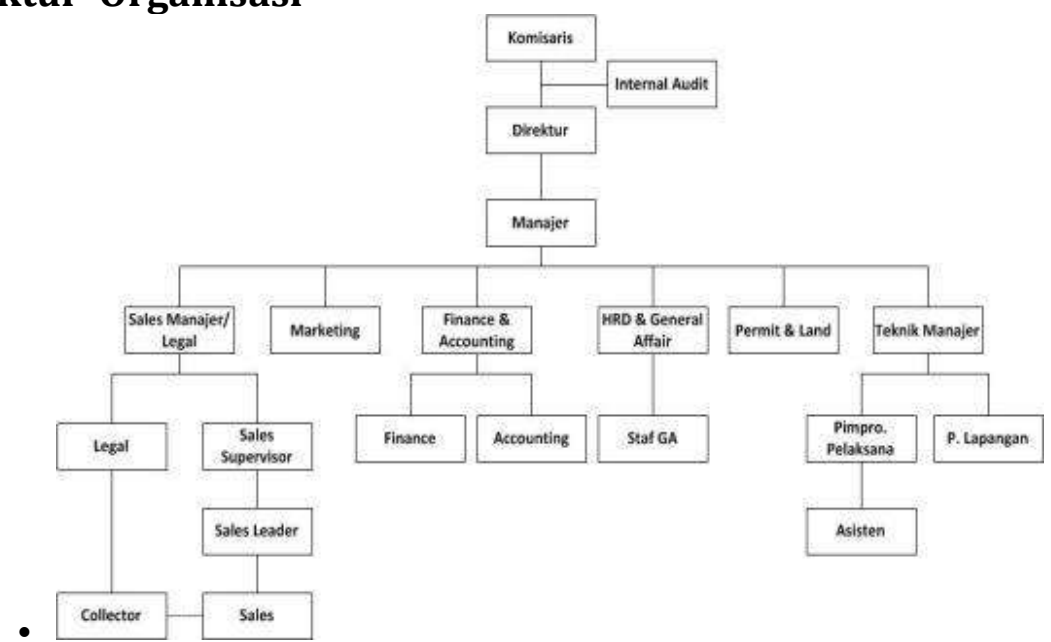

\section{b. Identifikasi Fungsi Bisnis}

Gambar 2. Struktur organisasi PT. Arcon Reality

Identifikasi dan pendefinisian fungsi bisnis PT. Arcon Realty tergambarkan melalui model analisis rantai nilai yang dapat dilihat pada gambar 3 dibawah ini. 


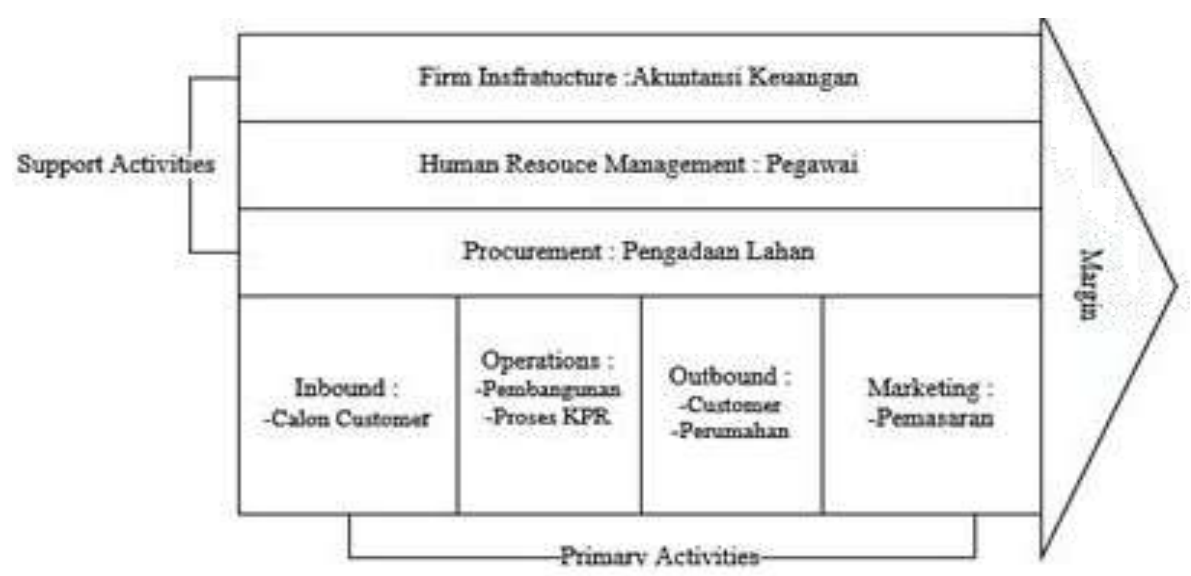

Gambar 3. Analisis Rantai Nilai PT. Arcon Realty

Realisasi fungsi dan unit bisnis pada perusahaan dapat disederhanakan melalui pemetaan seperti pada tabel 2 berikut ini.

Tabel 2. Pemetaan Fungsi Bisnis dan Unit Bisnis pada PT. Arcon Realty.

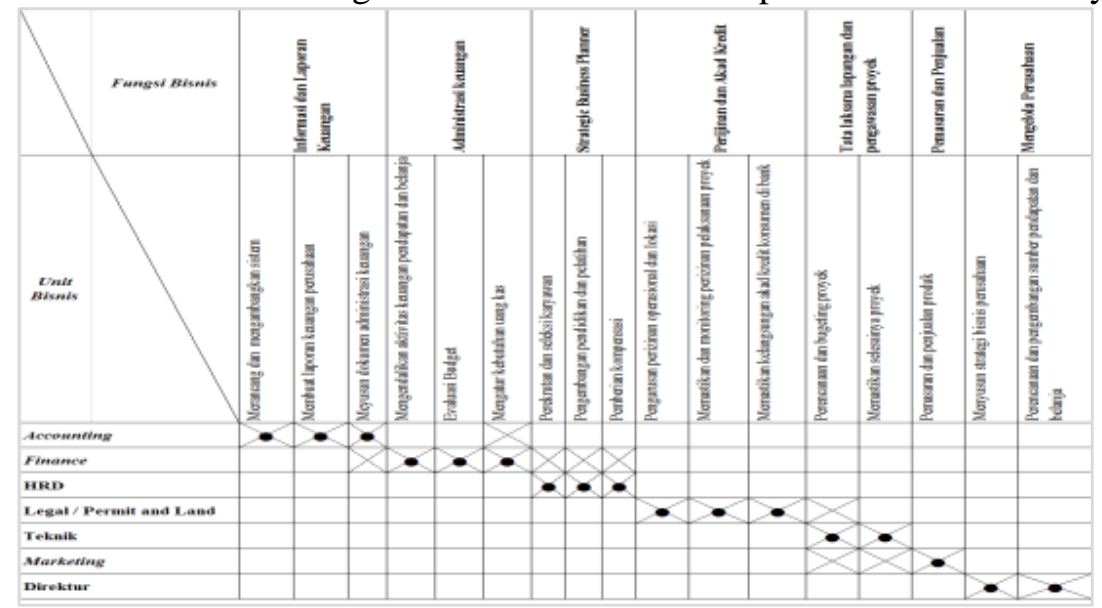

Proses identifikasi dan pendifinisan proses bisnis pada PT. Arcon Realty terpetakan melalui model seperti gambar 4 berikut ini. 


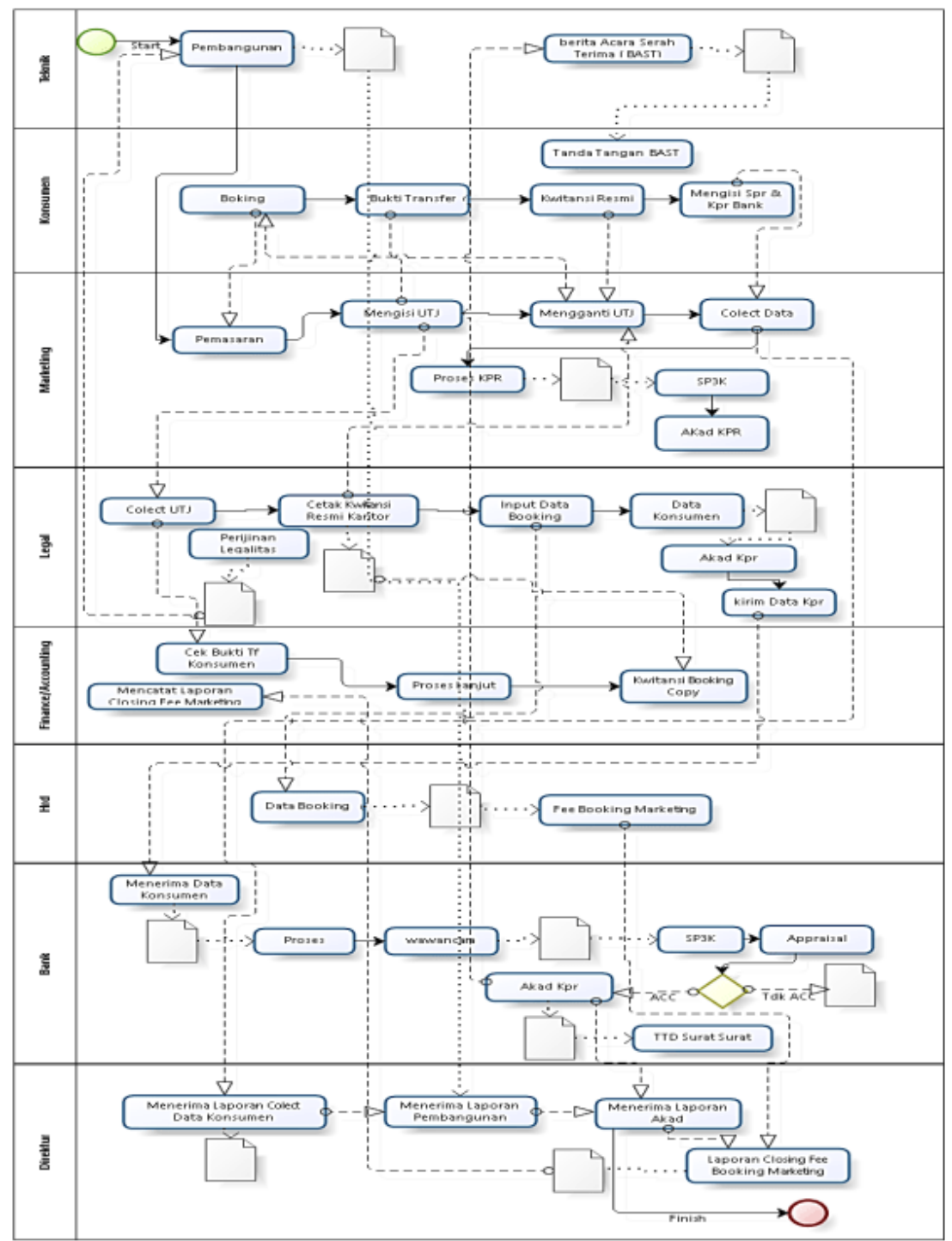

Gambar 4. Proses Bisnis Menggunakan BPMN

\section{Sistem dan Teknologi PT. Arcon Reality (Existing)}

\section{a. Koleksi Data IRC}

Pada tahapan ini merupakan pendefinisian dari keseluruhan platform teknologi dan sistem informasi yang digunakan pada saat ini. Berdasarkan hasil studi observasi dan wawancara dalam menentukan ruang lingkup dan sasaran information resource catalog (IRC) menghasilkan identifikasi sistem informasi yang digunakan dan peranannya terhadap fungsi bisnis (Astri \& Gaol, 2013; Setiawati et al., 2013)(Setiawati et al., 2013). Pemetaan kondisi pemanfaatan sistem dan teknologi pada PT. Arcon Reality saat ini, tergambarkan pada tabel 3 dan gambar 5 di bawah ini. 
Tabel 3. Pemetaan fungsi bisnis dan sistem informasi (existing)

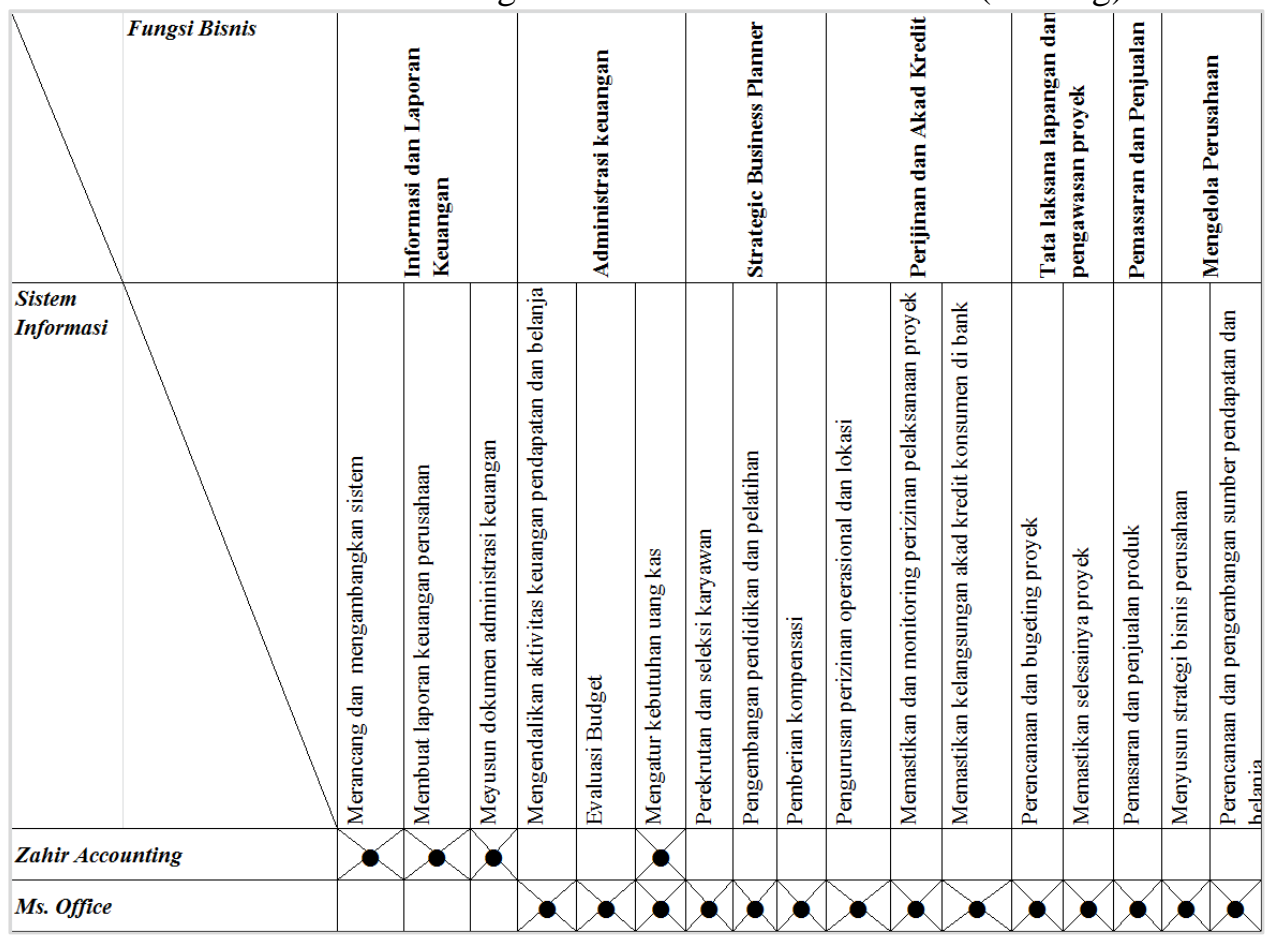

\section{b. Infrastruktur Teknologi Jaringan (Existing)}

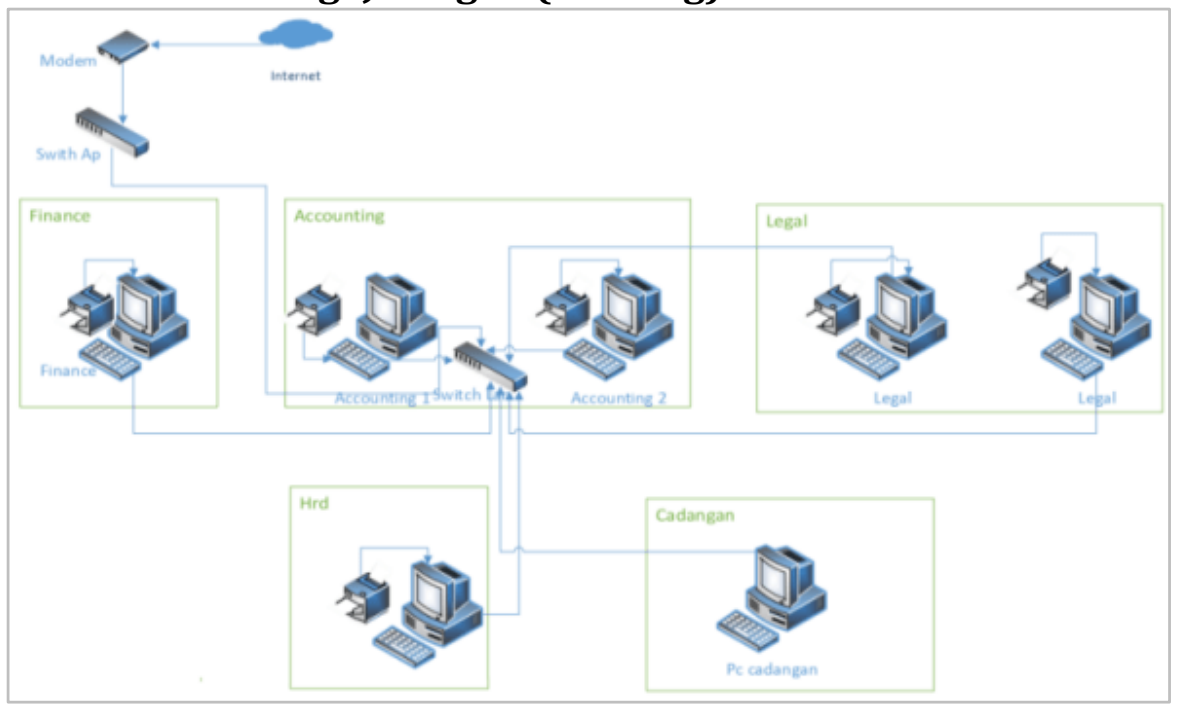

Gambar 5. Infrastuktur Teknologi Jaringan Komputer (Existing)

\section{Data Architecture}

Arsitektur data adalah konstruk arsitektur paling awal dari ketiga arsitektur yang sedang berjalan karena mutu suatu data adalah pondasi inti dari sebuah produk sistem informasi (Spewak \& Hill, 1993; Steven \& Michael, 2006). Arsitektur data terdiri dari atas entitas data dimana dari setiap entitas mengandung atribut serta hubungan dengan entitas lainnya (Spewak \& Hill, 1993).

\section{a. Konstruk Daftar Entitas Data}

Arsitektur data memiliki tujuan yaitu pengidentifikasian dan pendefinisian kebutuhan perusahaan terhadap data yang memiliki dukungan pada fungsi bisnis. Arsitektur data mendeskripsikan keseluruhan dari entitas data yang akan digunakan pada semua fungsi bisnis (Zaliluddin, 2015). Berikut 
merupakan daftar entitas yang ada di PT. Arcon Realty, sebagaimaan tertuang pada table 4 di bawah ini.

Tabel 4. Pemetaan Daftar Entitas

\begin{tabular}{|c|c|c|c|c|c|c|c|}
\hline No. & Entitas & No. & Entitas & No. & Entitas & No & Entitas \\
\hline 1. & Konsumen & 18. & Kas Keluar & 35. & Pembuatan & 52. & Lama Kredit \\
\hline 2. & Produk & 19. & Rekonsiliasi Bank & 36. & Rumah & 53. & Absensi \\
\hline 3. & Kavling & 20. & Penerimaan & 37. & Spesifikasi & 54. & Pegawai \\
\hline 4. & Lokasi & 21. & Pembelian & 38. & Pemesan & 55. & Cuti \\
\hline 5. & Renovasi & 22. & Buku Besar & 39. & Penjadwalan & 56. & Pensiun \\
\hline 6. & Simulasi & 23. & Gaji & 40. & Profil & 57. & Pengunduran \\
\hline 7. & Invoice & 24. & Tunjangan & 41. & Investor & 58. & Surat Peringatan \\
\hline 8 & KPR & 25. & Bonus & 42. & Mitra & 59. & Diklat \\
\hline 9 & PKS & 26. & Surat Masuk & 43. & Kontak & 60. & Jabatan \\
\hline 10. & Berkas Konsumen & 27. & Surat Keluar & 44. & Kategori & 61. & Dinas Luar \\
\hline 11. & Pajak & 28. & Kode Arsip & 45. & Blok & 62. & Izin \\
\hline 12 & KAS & 29. & Sertifikat & 46. & Foto & 63. & Kontrak Kerja \\
\hline 13 & Biaya Akad & 30. & Pemohon & 47. & Tipe & 64. & Jadwal Kerja \\
\hline 14 & Legalitas & 31. & Data Peta Bidang & 49. & Pemesanan & & \\
\hline 15 & Pembayaran & 33. & Material & 50. & Tunai & & \\
\hline 17 & Kas Masuk & 34. & Pembelian Material & 51. & Kredit & & \\
\hline
\end{tabular}

\section{b. Relasi Entitas Data Dengan Fungsi Bisnis}

Hubungan masing-masing entitas data terhadap fungsi bisnis dapat didefinisikan melalui identifikasi setiap entitas data yang digunakan pada fungsi bisnis. Hubungan tersebut dideskripsikan melalui pemetaan seperti pada tabel 5 di bawah ini.

Tabel 5. Pemetaan Relasi entitas data dengan fungsi bisnis

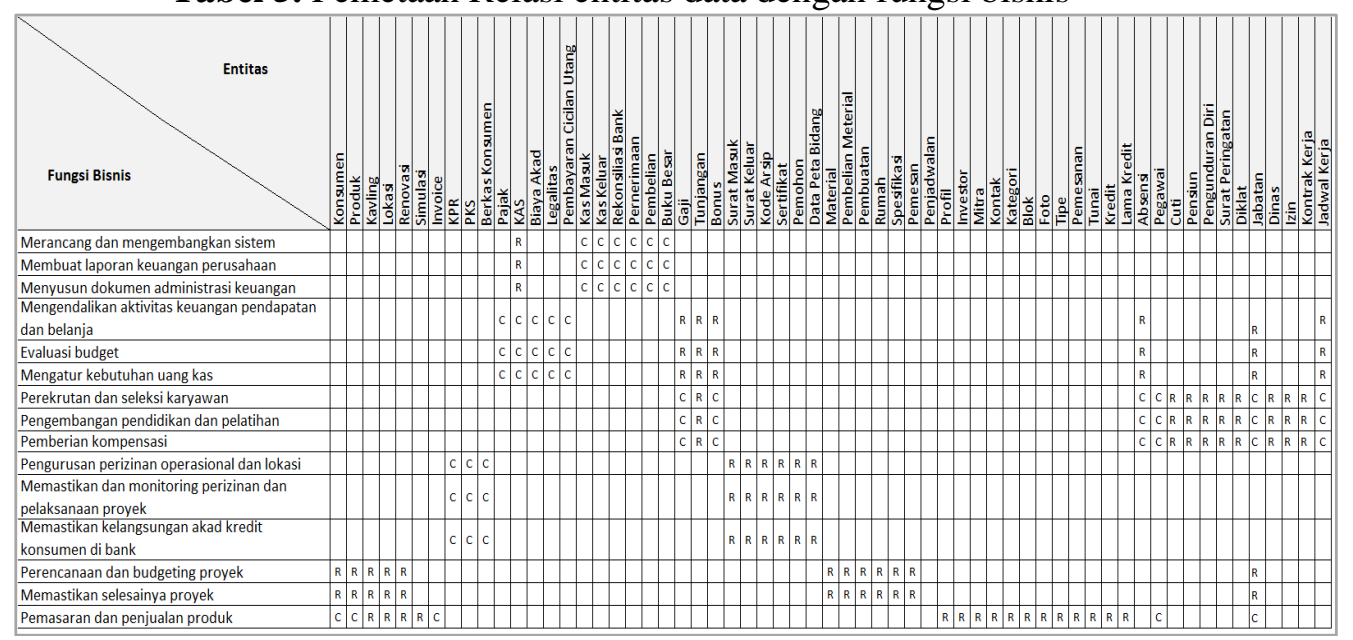

\section{Application Architecture}

Arsitektur Aplikasi merupakan proses pendefinisian kerangka kerja solusi aplikasi organisasi terhadap kebutuhan bisnis untuk mengelola data dan mendukung fungsi-fungsi bisnis (Witanti et al., 2016). Kandidat aplikasi dibangun berdasarkan relasi entitas data dengan fungsi bisnis yang ada, berdasarkan pengkajian penulis perlu adanya eksplorasi dan pengembangan sistem informasi untuk kedepannya. Dengan demikian yang diusulkan ini memastikan lanskap aplikasi dapat diskalakan, andal, dan dapat dikelola. Berikut merupakan pemodelan arsitektur aplikasi yang tertuang pada gambar 6 di bawah ini. 


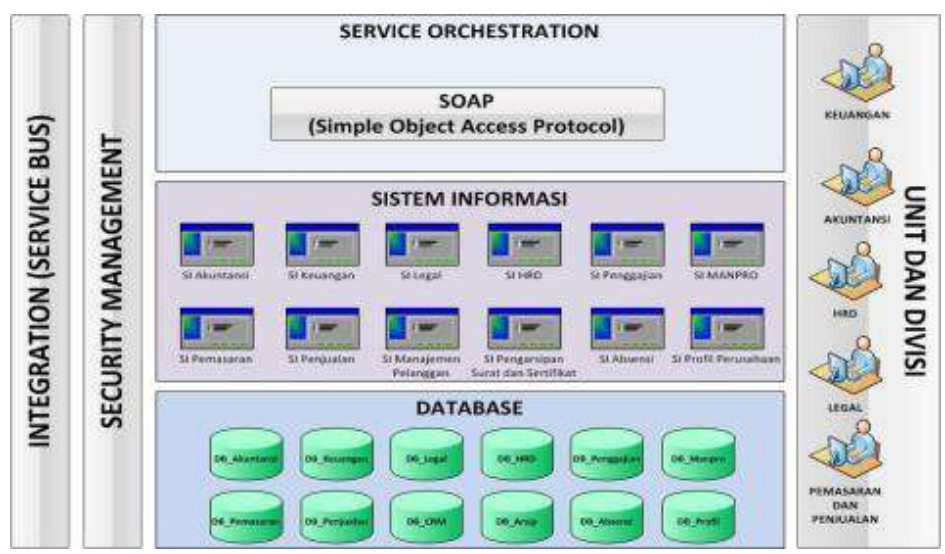

Gambar 6. Application Architecture

\section{Technology Architecture}

Pada tahap ini, merupakan tahapan dalam pendefinisian arsitektur teknologi untuk masa mendatang. Berdasarkan pengidentifikasian teknologi existing bahwa PT. Arcon Realty membutuhkan perubahan dari sisi penerapan teknologi untuk mendukung aktivitas bisnis perusahaan dengan mempertimbangkan adanya perluasan perusahaan dengan membuka anak perusahaan atau cabang kota lainnya. Detail proses pendefinisian arsitektur teknologi dibuat ke dalam bentuk katalog portofolio teknologi, seperti tertuang pada table 6 dan gambar 7 dibawah ini.

Tabel 6. Technology Portofolio Catalog

\begin{tabular}{|c|c|c|c|}
\hline No. & Hardware & Software & Keterangan \\
\hline 1. & Server & $\begin{array}{l}\text { Sistem Operasi } \\
\text { Windows Server } \\
\text { RDBMS : SQL Server }\end{array}$ & 1 (Satu) Server Database \\
\hline 2. & $\begin{array}{l}\text { PC Thin } \\
\text { Client }\end{array}$ & $\begin{array}{l}\text { Sistem Operasi } \\
\text { Windows }\end{array}$ & $\begin{array}{l}5 \text { (Lima) PC Thin Client: } \\
\text { - } \quad \text { Divisi Akuntansi } \\
\text { - } \quad \text { Divisi Keuangan } \\
\text { - } \text { Divisi Legal } \\
\text { - } \quad \text { Divisi Teknik } \\
\text { - } \quad \text { Divisi HRD } \\
5 \text { (Lima) PC Thin Client : } \\
\text { - } \quad \text { Kantor Cabang dengan divisi yang sama }\end{array}$ \\
\hline 3. & Laptop & $\begin{array}{l}\text { Sistem Operasi } \\
\text { Windows }\end{array}$ & $\begin{array}{ll}: \quad \text { Direktur }(1 \text { unit PC) } \\
\quad-\quad \text { Kepala Bagian/ Manajer (1 unit PC) }\end{array}$ \\
\hline 3. & $\begin{array}{l}\text { Face print } \\
\text { Machine }\end{array}$ & - & $\begin{array}{l}2 \text { (Dua) buah mesin Face Print (Pusat dan } \\
\text { cabang). }\end{array}$ \\
\hline 4. & Fax. & - & 2 (Dua) buah Fax untuk (Pusat dan cabang). \\
\hline 5. & Scanner & - & 4 (Empat) buah scanner (Pusat dan cabang). \\
\hline 6. & UPS & - & $\begin{array}{l}12 \text { (Dua belas) UPS pada setiap PC (Pusat } \\
\text { dan cabang) }\end{array}$ \\
\hline 7. & Switch & - & 2 (Dua) buat switch (Pusat dan cabang) \\
\hline 8. & Router & - & 2 (Dua) buat router (Pusat dan cabang) \\
\hline 9. & Internet & ISP : Telkom & 2 Paket Internet Office (Pusat dan cabang) \\
\hline
\end{tabular}

Berikut merupakan skema dari pemetaan infrastuktur teknologi dan jaringan melalui pemodelan desain lingkungan dan lokasi teknologi untuk diimplementasikan pada PT. Arcon Realty, seperti terpetakan pada gambar 7 di bawah ini. 


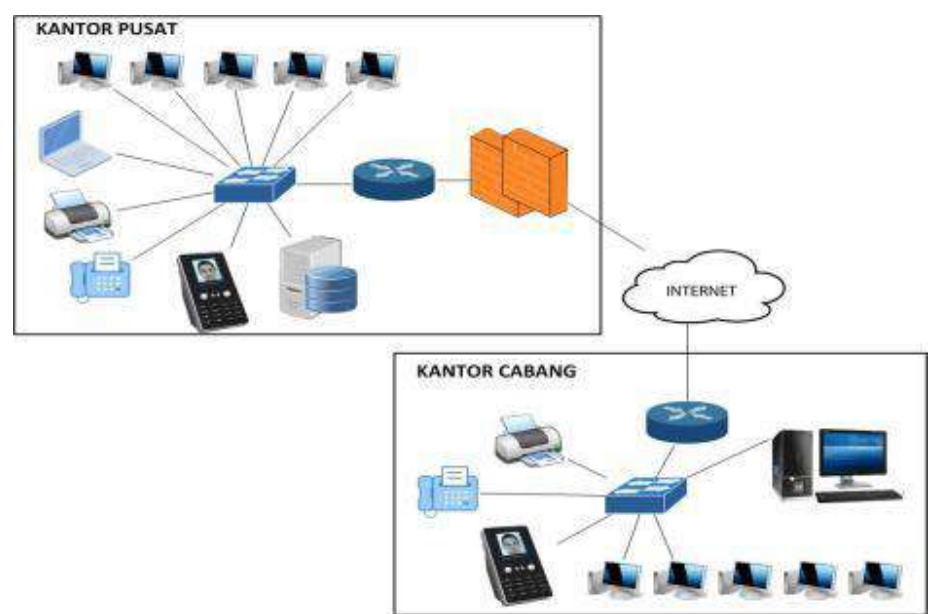

Gambar 7. Infrastruktur Teknologi Jaringan Komputer (Usulan)

\section{Rencana Implementasi}

Perencanaan dan implementasi memiliki tujuan sebagai formulasi dan persiapan dalam rangka merealisisasikan arsitektur yang dihasilkan (Surendro, 2007), sehingga akan memberikan optimalisasi terhadap aktivitas bisnis perusahaan.

\section{a. Portofolio Aplikasi}

Berdasarkan pengelompokan sistem informasi melalui portofolio aplikasi model Mc Farlan (Sylvia \& Angela, 2019), maka dapat dikelompokkan sebagaimana dijelaskan pada tabel 7 di bawah ini.

Tabel 7. Protofolio Aplikasi

\begin{tabular}{ll}
\hline \multicolumn{1}{c}{ Strategi } & \multicolumn{1}{c}{ Berpotensi Tinggi } \\
\hline $\begin{array}{l}\text { Sistem Informasi Accounting } \\
\text { Sistem Informasi Keuangan }\end{array}$ & $\begin{array}{l}\text { Sistem Informasi Legal } \\
\text { Sistem Informasi HRD } \\
\text { Sistem Informasi Penggajian }\end{array}$ \\
\hline \multicolumn{1}{c}{ Kunci Operasional } & \multicolumn{1}{c}{ Pendukung } \\
\hline Sistem Informasi Pemasaran & Sistem Informasi Absensi \\
Sistem Informasi Penjualan & Sistem Informasi Manajemen Proyek \\
Sistem informasi Pengarsipan Surat & Sistem Informasi Profil Perusahaan \\
dan Sertifikat Rumah & \\
\hline
\end{tabular}

\section{b. Roadmap Rencana Implementasi}

Pendefinisian urutan prioritas pengembangan aplikasi dari aspek kebutuhan perusahaan ditungkan melalui model roadmap (Rerung, 2017), sebagaimana dapat dilihat pada gambar 8 berikut ini.

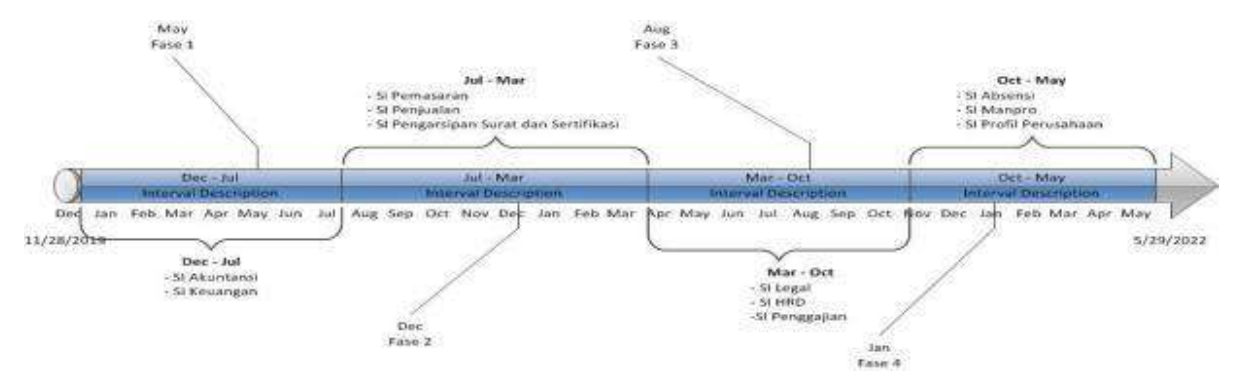

Gambar 8. Roadmap Rencana Implementasi 


\section{REFERENSI}

Astri, L. Y., \& Gaol, F. L. (2013). INFORMATION SYSTEM STRATEGIC PLANNING WITH ENTERPRISE ARCHITECTURE PLANNING. CommIT (Communication and Information Technology) Journal. https://doi.org/10.21512/commit.v7i1.580

Ati, S., Nurdien, Kistanto, \& Taufik, A. (2014). Pengantar Konsep Informasi, Data, dan Pengetahuan. Universitas Terbuka.

Chew, E. K., \& Gottschalk, P. (2012). Knowledge driven service innovation and management: IT strategies for business alignment and value creation. In Knowledge Driven Service Innovation and Management: IT Strategies for Business Alignment and Value Creation. https://doi.org/10.4018/978-1-4666-2512-9

Indrayani, H. (2012). PENERAPAN TEKNOLOGI INFORMASI DALAM PENINGKATAN EFEKTIVITAS, EFISIENSI DAN PRODUKTIVITAS PERUSAHAAN. Jurnal EL-RIYASAH. https://doi.org/10.24014/jel.v3i1.664

Kurniawan, A. P., \& Chazar, C. (2015). Perencanaan Cetak Biru Sistem Informasi Terintegrasi Berbasis E2AF dan Metodologi EAP. Jurnal Informasi.

Rerung, R. R. (2017). PERENCANAAN ARSITEKTUR SISTEM INFORMASI DINAS PARIWISATA MENGGUNAKAN MODEL EAP. Simetris: Jurnal Teknik Mesin, Elektro Dan Ilmu Komputer. https://doi.org/10.24176/simet.v8i1.997

Rozak, N. S., Prasetyo, Y. A., \& Mulyana, R. (2017). Perancangan Enterprise Architecture pada fungsi operasional dan pelayanan publik Perum Bulog Divre Jawa Barat menggunakan framework TOGAF ADM. E-Proceeding of Engineering.

Setiawati, E., Wibowo, A., \& Yulia, Y. (2013). Perancangan Sistem Informasi Enterprise Architecture Di PT. ABC. Jurnal Infra, 1(2).

Solihin, H. (2015). PERANCANGAN ENTERPRISE ARCHITECTURE UNTUK PENERAPAN MANAJEMEN INOVASI MENGGUNAKAN ZACHMAN FRAMEWORK PADA PUSAT PENELITIAN TENAGA LISTRIK DAN MEKATRONIK LEMBAGA ILMU PENGETAHUAN INDONESIA. https://doi.org/10.5281/zenodo.1495826

Spewak, S., \& Hill, S. (1993). Enterprise Architecture Planning: Developing a Blueprint for Data, Applications and Technology.

Steven, S., \& Michael, T. (2006). Updating the Enterprise Architecture Planning Model. Journal of Enterprise Architecture.

Surendro, K. (2007). PEMANFAATAN ENTERPRISE ARCHITECTURE PLANNING UNTUK PERENCANAAN STRATEGIS SISTEM INFORMASI. Jurnal Informatika, 8.

Sylvia, C., \& Angela, A. (2019). PERENCANAAN STRATEGIS SISTEM DAN TEKNOLOGI INFORMASI PADA STMIK - STIE MIKROSKIL MENGGUNAKAN METODE WARD \& PEPPARD. Sebatik. https://doi.org/10.46984/sebatik.v23i2.816

Witanti, W., Hadiana, A. I., \& Ramadhan, R. F. (2016). Arsitektur Teknologi Informasi Berbasis Enterprise Architecture Planning (EAP) di Badan Meteorologi Klimatologi Geofisika ( BMKG ). Annual Research Seminar 2016.

Zaliluddin, D. (2015). Enterprise Architecture Planning Sistem Informasi Perusahaan Manufaktur (Studi Kasus: CV. Harta Jaya Perusahaan). Infotech Journal, 1(1). https://doi.org/10.31949/inf.v1i1.30 